RESEARCH PAPER RP1411

Part of Journal of Research of the National Bureau of Standards, Volume 27, August 1941

\title{
RELATIONSHIP OF THE GARNET-HYDROGARNET SERIES TO THE SULFATE RESISTANCE OF PORTLAND CEMENTS
}

\author{
By E. P. Flint and Lansing S. Wells
}

\begin{abstract}
Isometric $3 \mathrm{CaO} \cdot \mathrm{Al}_{2} \mathrm{O}_{3} \cdot 6 \mathrm{H}_{2} \mathrm{O}$, a constituent of set portland cement, is readily converted by sodium sulfate solutions to $3 \mathrm{CaO} \cdot \mathrm{Al}_{2} \mathrm{O}_{3} \cdot 3 \mathrm{CaSO}_{4} \cdot 31.5 \mathrm{H}_{2} \mathrm{O}$. Partial replacement of the $\mathrm{Al}_{2} \mathrm{O}_{3}$ in $3 \mathrm{CaO} . \mathrm{Al}_{2} \mathrm{O}_{3} \cdot 6 \mathrm{H}_{2} \mathrm{O}$ by $\mathrm{Fe}_{2} \mathrm{O}_{3}$ or of the $\mathrm{H}_{2} \mathrm{O}$ by $\mathrm{SiO}_{2}$ gives "hydrogarnets" which are stable in the presence of sulfate solutions. Such substitutions may be brought about by inducing reactions between tricalcium aluminate hydrate and silica from various sources in the set cement or from added puzzolanic materials, and by increasing the content of glass and tetracalcium aluminoferrite in the cement.

Products having an X-ray structure nearly identical with that of grossularite garnet result when properly proportioned mixtures, made up of the puzzolanic material, dehydrated kaolin, with tricalcium silicate, or with lime and beta dicalcium silicate, are steamed at $500^{\circ} \mathrm{C}$ and 420 atmospheres.
\end{abstract}

\section{CONTENTS}

I. Introduction

II. Resistance of hydrogarnets to sodium sulfate solution $\ldots \ldots \ldots \ldots$

1. Method of testing

2. Results $\ldots$

III. Effect of hydrothermal treatment of mixtures of aluminates and silicates on the sulfate resistance of cements... 174

1. Method of study

2. Products of hydrothermal treatment of aluminate silicate mixtures _. 174

3. Relationship of results to curing of portland cement mortar or concrete.

IV. Effect of hydrothermal reactions of cement compounds with burntclay puzzolana on the sulfate resistance of cements.

1. Materials and procedure

2. Results of hydrothermal treatment.

3. Application to portland-puzzolana cements

V. Effect of increase in glass content on the sulfate resistance of cements _- 179

VI. Effect of increasing alumina-ferric oxide ratio on the sulfate resistance of cements

VII. Summary

VIII. References_.

\section{INTRODUCTION}

Various investigators [1] ${ }^{1}$ have demonstrated the existence of a general correlation between the potential tricalcium aluminate content of portland cements of low glass content and the resistance to sulfate action of mortars and concretes made from these cements. The typical reaction which occurs during sulfate disintegration in-

\footnotetext{
1 Numbers in brackets indicate the references at the end of the paper.
} 
volves conversion of the hydration products of tricalcium aluminate to gypsum and the "high-sulfate form" of calcium sulfoaluminate, $3 \mathrm{CaO} . \mathrm{Al}_{2} \mathrm{O}_{3} \cdot 3 \mathrm{CaSO}_{4} \cdot 31.5 \mathrm{H}_{2} \mathrm{O}$. This transformation is accompanied by considerable expansion which eventually may disrupt the specimen.

There are a number of methods by which the sulfate resistance of portland cement mortar or concrete can be increased, including the following:

(1) Steaming the mortar or concrete [2].

(2) Prolonged curing of the mortar or concrete at ordinary temperatures [3].

(3) Mixing the cement with a puzzolanic material [4].

(4) Increasing the glass content of the cement [5].

(5) Altering the chemical composition of the cement [3].

In view of the relationship between the tricalcium aluminate content and disintegration tendency of the cement, it seemed probable that these methods might be efficacious in the degree to which they convert the aluminate content of the set cement into a form not readily attacked by sulfate solutions. Recent work [6] suggested that this stabilized aluminate might consist of silica- or iron-containing hydrogarnet. Experiments which support this hypothesis have been made and are reported in this paper.

\section{RESISTANCE OF HYDROGARNETS TO SODIUM SULFATE SOLUTION}

\section{METHOD OF TESTING}

Samples of hydrogarnet preparations having compositions shown in figure 1 were available from a previous study. The isometric tricalcium aluminate hexahydrate (1, fig. 1), prepared by treating anhydrous tricalcium aluminate with steam at $150^{\circ} \mathrm{C}$ in an autoclave, was practically free from silica and ferric oxide. The tricalcium ferrite hexahydrate $(8$, fig. 1$)$ was obtained by reaction of ferric chloride solution with boiling limewater. This preparation contained a certain amount of silica, probably combined as hydrated calcium silicate, since a determination of the unit cell size of the sample gave practically the theoretical value for $3 \mathrm{CaO} \cdot \mathrm{Fe}_{2} \mathrm{O}_{3} \cdot 6 \mathrm{H}_{2} \mathrm{O}$.

A sulfate test solution was desired which would contain a sufficient concentration of calcium ions to prevent undue hrydolysis of the hydrogarnet preparations placed in contact with it. Such a solution was prepared by mixing $100 \mathrm{~g}$ of anhydrous sodium sulfate with 1 liter of saturated lime solution ( $1.15 \mathrm{~g}$ of $\mathrm{CaO}$ per liter). The resulting mixture was slightly supersaturated with respect to gypsum and some precipitation of this compound occurred. To 100-ml quantities of the test solution, in tightly-stoppered flasks, 0.5 -g samples of the hydrogarnet preparations were added. The flasks were allowed to stand with occasional daily shaking. Small samples of the solid phases were filtered off at intervals and examined microscopically.

\section{RESULTS}

Transformation of the $3 \mathrm{CaO} \cdot \mathrm{Al}_{2} \mathrm{O}_{3} \cdot 6 \mathrm{H}_{2} \mathrm{O}$ to well-developed needles of the "high-sulfate form" of sulfoaluminate, $3 \mathrm{CaO} \cdot \mathrm{Al}_{2} \mathrm{O}_{3} \cdot 3 \mathrm{CaSO}_{4}$; $31.5 \mathrm{H}_{2} \mathrm{O}$, began within a few hours and was complete after 2 days' 
contact with the sulfate solution. The sulfoaluminate was unchanged by standing 6 months longer in contact with the solution.

The aluminate preparation containing no ferric oxide and only 7.7 percent of silica (2, fig. 1) was not perceptibly altered until after about 4 months when a very small amount of finely divided material having the mean refractive index of the sulfoaluminate appeared. This product increased to about 10 percent of the sample in 6 months. Preparations 4 and 5, fig. 1, which had $\mathrm{Al}_{2} \mathrm{O}_{3}: \mathrm{Fe}_{2} \mathrm{O}_{3}$ molar ratios of $2: 1$ (12.8 percent of $\mathrm{Fe}_{2} \mathrm{O}_{3}$ ) and 1:1 (18.4 percent of $\mathrm{Fe}_{2} \mathrm{O}_{3}$ ) and contained the lowest amounts of silica, showed a small amount of apparently amorphous material surrounding the isometric crystals after 6 months'

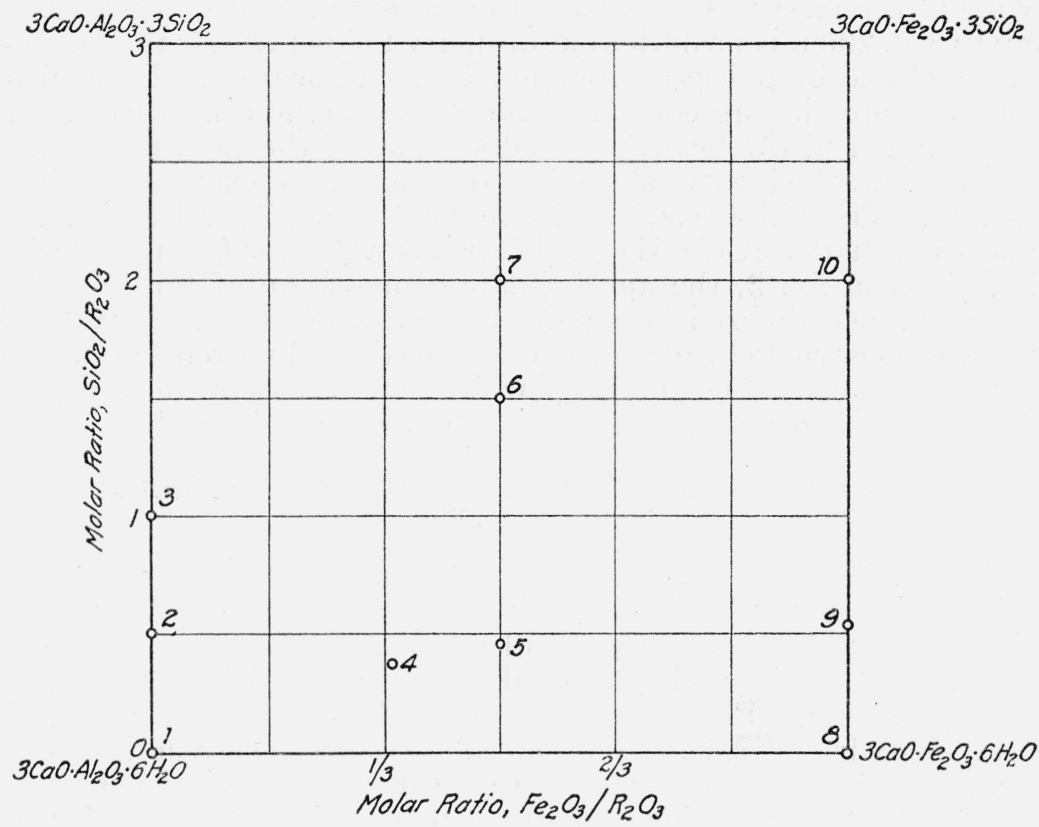

Figure 1.-Compositions of members of garnet-hydrogarnet series exposed to sodium sulfate solution.

contact with the sulfate solution. No appreciable alteration of any of the other preparations tested was observed during the 6-months' period.

Thus the hydrogarnets which contain 10 to 15 percent or more of either silica or ferric oxide appear to be very resistant to transformation by the sulfate test solution. It can be postulated, therefore, that the sulfate resistance of set portland cements will be greatly improved if the aluminate compounds which they contain are converted to silica- or iron-containing hydrogarnets. The remainder of this paper will attempt to show how this is accomplished by the various methods already mentioned. 


\section{EFFECT OF HYDROTHERMAL TREATMENT OF MIX- TURES OF ALUMINATES AND SILICATES ON THE SUL- FATE RESISTANCE OF CEMENTS}

\section{METHOD OF STUDY}

Mixtures of isometric $3 \mathrm{CaO} \cdot \mathrm{Al}_{2} \mathrm{O}_{3} \cdot 6 \mathrm{H}_{2} \mathrm{O}$ with definite amounts of various hydrated calcium silicates were prepared for treatment with water over a range of temperatures. A few mixtures of anhydrous tricalcium aluminate and the anhydrous calcium silicates were also included. The synthesis of the hydrated calcium silicates has been described in an earlier publication [7].

Some of the mixtures were placed in saturated lime solution $(0.5 \mathrm{~g}$ of mixture in $200 \mathrm{ml}$ of solution) at ordinary temperatures; the remainder were placed in high-pressure autoclaves and heated with sufficient water to insure the presence of liquid at the temperatures used. At the completion of the heating period samples of the solid phase were withdrawn, washed with alcohol and ether, and examined microscopically. From the relationship between index of refraction and composition in the $3 \mathrm{CaO} \cdot \mathrm{Al}_{2} \mathrm{O}_{3} \cdot 6 \mathrm{H}_{2} \mathrm{O}-3 \mathrm{CaO} \cdot \mathrm{Al}_{2} \mathrm{O}_{3} \cdot 3 \mathrm{SiO}_{2}$ solid-solution series, given in fig. 2, the approximate composition of the isometric phase could be estimated from a determination of its refractive index. Fig. 2 was constructed from index of refraction values reported in the literature for $3 \mathrm{CaO} \cdot \mathrm{Al}_{2} \mathrm{O}_{3} \cdot 6 \mathrm{H}_{2} \mathrm{O}$, plazolite, and grossularite, and from values for two synthetic preparations obtained in this study.

\section{PRODUCTS OF HYDROTHERMAL TREATMENT OF ALUMINATE SILICATE MIXTURES}

Owing to the very different rates of reaction with water of the aluminate and silicate compounds in cement, it is probable that tricalcium aluminate hexahydrate will occur in set cement associated with hydrated calcium silicates of different compositions and stages of crystallization. However, if such products are unstable with respect to hydrated calcium aluminosilicates, further reactions may occur. Restricting consideration to mixtures having the molar ratio $1 \mathrm{Al}_{2} \mathrm{O}_{3}: 1 \mathrm{SiO}_{2}$, the following bypothetical equations may be formulated:

$$
\begin{gathered}
3 \mathrm{CaO} \cdot \mathrm{Al}_{2} \mathrm{O}_{3} \cdot 6 \mathrm{H}_{2} \mathrm{O}+\mathrm{SiO}_{2}=3 \mathrm{CaO} \cdot \mathrm{Al}_{2} \mathrm{O}_{3} \cdot \mathrm{SiO}_{2} \cdot 4 \mathrm{H}_{2} \mathrm{O}+2 \mathrm{H}_{2} \mathrm{O} . \\
3 \mathrm{CaO} \cdot \mathrm{Al}_{2} \mathrm{O}_{3} \cdot 6 \mathrm{H}_{2} \mathrm{O}+\mathrm{CaO}: \mathrm{SiO}_{2}: \mathrm{aq}=3 \mathrm{CaO} \cdot \mathrm{Al}_{2} \mathrm{O}_{3} \cdot \mathrm{SiO}_{2} \cdot 4 \mathrm{H}_{2} \mathrm{O}+\mathrm{Ca}(\mathrm{OH})_{2}+\mathrm{aq} . \\
3 \mathrm{CaO} \cdot \mathrm{Al}_{2} \mathrm{O}_{3} \cdot 6 \mathrm{H}_{2} \mathrm{O}+2 \mathrm{CaO} \cdot \mathrm{SiO}_{2} \cdot \mathrm{H}_{2} \mathrm{O}=3 \mathrm{CaO} \cdot \mathrm{Al}_{2} \mathrm{O}_{3} \cdot \mathrm{SiO}_{2} \cdot 4 \mathrm{H}_{2} \mathrm{O}+2 \mathrm{Ca}(\mathrm{OH})_{2} \\
+\mathrm{H}_{2} \mathrm{O} . \\
3 \mathrm{CaO} \cdot \mathrm{Al}_{2} \mathrm{O}_{3} \cdot 6 \mathrm{H}_{2} \mathrm{O}+3 \mathrm{CaO} \cdot \mathrm{SiO}_{2} \cdot 2 \mathrm{H}_{2} \mathrm{O}=3 \mathrm{CaO} \cdot \mathrm{Al}_{2} \mathrm{O}_{3} \cdot \mathrm{SiO}_{2} \cdot 4 \mathrm{H}_{2} \mathrm{O}+3 \mathrm{Ca}(\mathrm{OH})_{2} \\
+\mathrm{H}_{2} \mathrm{O} .
\end{gathered}
$$

According to figure 2, the index of refraction of $3 \mathrm{CaO} \cdot \mathrm{Al}_{2} \mathrm{O}_{3} \cdot \mathrm{SiO}_{2}$. $4 \mathrm{H}_{2} \mathrm{O}$ is approximately 1.63 . Therefore, if the above reactions proceed to completion, the products will consist entirely of calcium hydroxide and an isometric phase of index 1.63. Table 1 shows that this condition is very nearly fulfilled in experiments $3,6,7,8$, and 11 , where sufficient time had been allowed at the temperatures given, for complete transformation of the original materials. In most cases, the index of refraction of the isometric phase was not uniform but showed a variation of about 0.01 unit. This variation is probably caused by imperfect mixing of the original samples and by difficulty in obtaining 
TABLE 1.-Formation of silica-containing hydrogarnets from mixtures of aluminates and silicates

\begin{tabular}{|c|c|c|c|c|c|c|c|}
\hline $\begin{array}{l}\text { Experi- } \\
\text { ment } \\
\text { number }\end{array}$ & Compounds mixed & $\begin{array}{c}\text { Molar ratio } \\
\mathrm{Al}_{2} \mathrm{O}_{3} / \mathrm{SiO}_{2} \text { in } \\
\text { mixture }\end{array}$ & $\begin{array}{l}\text { Tem- } \\
\text { pera- } \\
\text { ture }\end{array}$ & $\begin{array}{l}\text { Pres- } \\
\text { sure }\end{array}$ & Time & $\begin{array}{l}\text { Index of refrac- } \\
\text { tion of iso- } \\
\text { metric phase in } \\
\text { product }\end{array}$ & Other phases in product \\
\hline $\begin{array}{r}1 \\
2 \\
3 \\
4 \\
5 \\
6 \\
7 \\
8 \\
9 \\
10 \\
11 \\
12 \\
13 \\
14 \\
15 \\
16 \\
17 \\
18\end{array}$ & 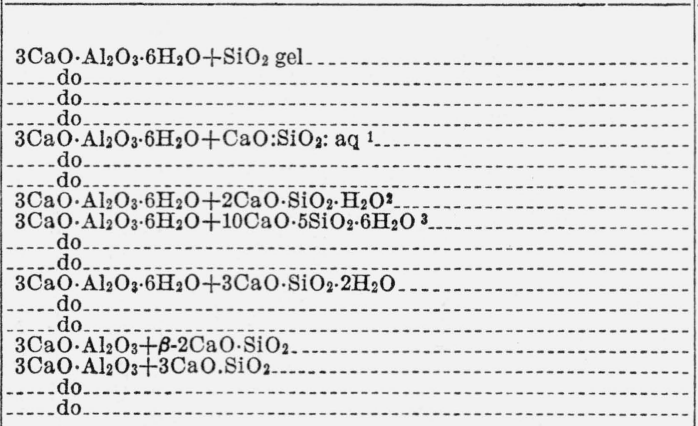 & $\begin{array}{l}1: 1 \\
1: 1 \\
1: 1 \\
1: 2 \\
1: 1 \\
1: 1 \\
1: 1 \\
1: 1 \\
1: 1 \\
1: 1 \\
1: 1 \\
1: 1 \\
1: 1 \\
1: 1 \\
1: 1 \\
2: 1 \\
1: 1 \\
1: 2\end{array}$ & $\begin{array}{r}{ }^{\circ} C \\
25 \\
150 \\
250 \\
350 \\
25 \\
150 \\
250 \\
250 \\
25 \\
150 \\
250 \\
25 \\
150 \\
250 \\
200 \\
200 \\
200 \\
350\end{array}$ & $\begin{array}{r}\text { Atmos- } \\
\text { pheres } \\
1 \\
5 \\
39 \\
163 \\
1 \\
5 \\
39 \\
39 \\
1 \\
5 \\
39 \\
1 \\
5 \\
39 \\
15 \\
15 \\
15 \\
163\end{array}$ & $\begin{array}{r}\text { Days } \\
92 \\
7 \\
18 \\
10 \\
54 \\
7 \\
21 \\
34 \\
54 \\
31 \\
7 \\
62 \\
32 \\
10 \\
12 \\
11 \\
5 \\
5\end{array}$ & $\begin{array}{l}1.605 \\
1.62 \text { to } 1.64 \\
1.63 \text { to } \\
1.67 \\
1.605 \text { to } 1.61 \\
1.625 \text { to } 1.635 \\
1.625 \text { to } 1.635 \\
1.63 \text { to } 1.625 \\
1.62 \text { to } 1.625 \\
1.62 \text { to } 1.635 \\
1.625 \text { to } \\
1.61 \text { to } 1.62 \\
1.62 \text { to } 1.625 \\
1.62 \text { to } 1.63 \\
1.62 \text { to } 1.63 \\
1.62 \text { to } 1.63 \\
1.62 \text { to } 1.63 \\
1.62 \text {. }\end{array}$ & $\begin{array}{l}\text { Amorphous, low-index material. } \\
\text { Do. } \\
\text { None. } \\
\text { Do. } \\
\text { Amorphous, low-index material. } \\
\mathrm{Ca}(\mathrm{OH})_{2} . \\
\text { Do. } \\
\text { Do. } \\
10 \mathrm{CaO} \cdot 5 \mathrm{SiO}_{2} \cdot 6 \mathrm{H}_{2} \mathrm{O}+\mathrm{Ca}(\mathrm{OH})_{2} . \\
\text { Do. } \\
\mathrm{Ca}(\mathrm{OH})_{2} . \\
3 \mathrm{CaO} \cdot \mathrm{SiO}_{2} \cdot 2 \mathrm{H}_{2} \mathrm{O}+\mathrm{Ca}(\mathrm{OH})_{2} . \\
\text { Do. } \\
\text { Do. } \\
10 \mathrm{CaO} \cdot 5 \mathrm{SiO}_{2} \cdot 6 \mathrm{H}_{2} \mathrm{O}+\mathrm{Ca}(\mathrm{OH})_{2} . \\
\text { Do. } \\
\text { Do. } \\
3 \mathrm{CaO} \cdot \mathrm{SiO}_{2} \cdot 2 \mathrm{H}_{2} \mathrm{O}+\mathrm{Ca}(\mathrm{OH})_{2} .\end{array}$ \\
\hline
\end{tabular}

1 Amorphous hydrated monocalcium silicate.

2 Needle-form of dicalcium silicate hydrate, mean index of refraction 1.60 (see reference [7]).

3 Orthorhombic dicalcium silicate hydrate, $\alpha=1.614, \beta=1.620, \gamma=1.633$ (see reference [7]). 
uniform reaction between crystals of low solubility. In experiment 3 , a rise in index of refraction of the isometric crystals to as much as 1.64 may have been caused by a concentration of silica in the outer portion of the crystals. Numerous crystals having the higher indices of refraction contained cores of lower index.

A mixture of tricalcium aluminate hexahydrate and silica gel in the molar proportion $1 \mathrm{Al}_{2} \mathrm{O}_{3}: 2 \mathrm{SiO}_{2}$, treated with water at $350^{\circ} \mathrm{C}$ for 10 days, was completely converted to an isometric phase having an index of refraction approximately that of plazolite, $3 \mathrm{CaO} \cdot \mathrm{Al}_{2} \mathrm{O}_{3}$.

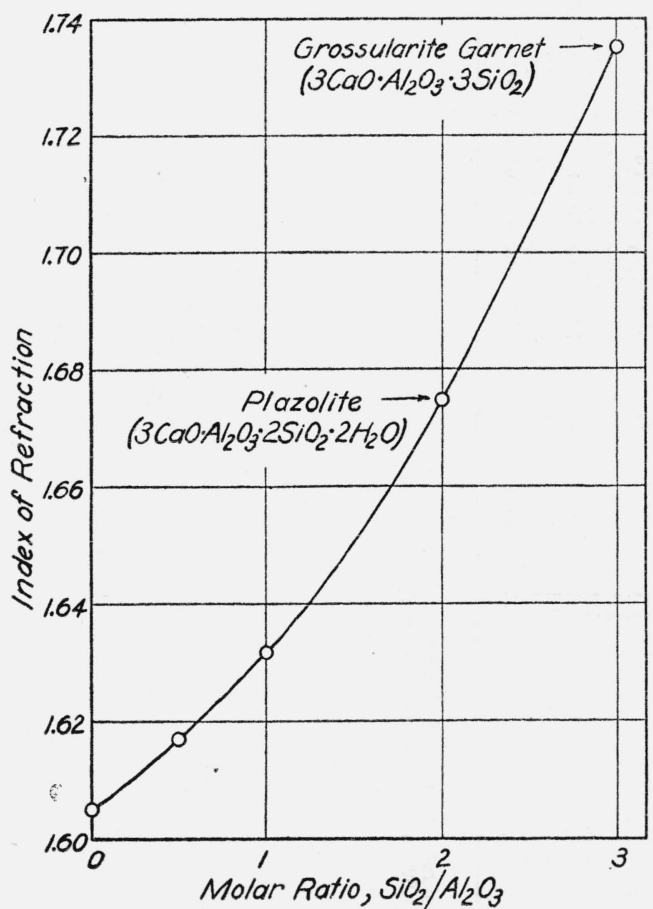

FIGURE 2-Relationship between index of refraction and composition in the solid-solution series $3 \mathrm{CaO} \cdot \mathrm{Al}_{2} \mathrm{O}_{3} \cdot 6 \mathrm{H}_{2} \mathrm{O}-3 \mathrm{CaO} \cdot \mathrm{Al}_{2} \mathrm{O}_{3} \cdot 3 \mathrm{SiO}_{2}$. gel (experiment 1) or amorphous hydrated monocalcium silicate (experiment 5), there is little evidence of such a reaction. It is possible that the amorphous reaction products in these experiments may form a layer of low permeability on the crystals of $3 \mathrm{CaO} \cdot \mathrm{Al}_{2} \mathrm{O}_{3} \cdot 6 \mathrm{H}_{2} \mathrm{O}$, thereby diminishing the rate of diffusion of silica into the aluminate.

\section{RELATIONSHIP OF RESULTS TO CURING OF PORTLAND CEMENT MORTAR OR CONCRETE}

It is well known that steam curing is one of the most effective means of increasing the sulfate resistance of portland cement mortars and concretes. The foregoing experiments show that the essential change produced by steam curing appears to be the removal from the set 
cement of tricalcium aluminate hexahydrate, which is unstable in the presence of sulfate solutions, and the formation of a silica-containing hydrogarnet, which is stable in such solutions. The crystallization of hydrated calcium silicates and reduction in free calcium hydroxide, which accompany steam treatment, are probably factors of less importance. In curing at ordinary temperatures, the formation of silicacontaining hydrogarnets may likewise be the determining factor. Both the rate of conversion of $3 \mathrm{CaO} \cdot \mathrm{Al}_{2} \mathrm{O}_{3} \cdot 6 \mathrm{H}_{2} \mathrm{O}$ and the improvement in sulfate resistance at such temperatures are very slow.

\section{EFFECT OF HYDROTHERMAL REACTIONS OF CEMENT COMPOUNDS WITH BURNT-CLAY PUZZOLANA ON THE SULFATE RESISTANCE OF CEMENTS}

\section{MATERIALS AND PROCEDURE}

Dehydrated Georgia kaolin was selected as a typical burnt-clay puzzolana. The original material, before ignition, had the following composition (analysis by F. W. Glaze):

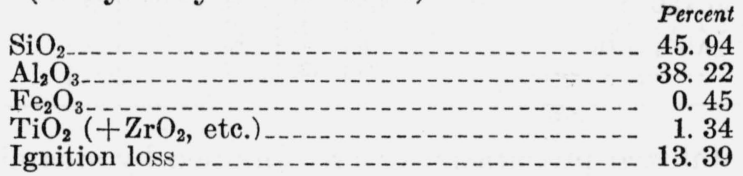

The kaolin was dehydrated by heating for 2 hours at $700^{\circ} \mathrm{C}$. Mixtures of this material with various cement compounds were then prepared and treated with water at elevated temperatures and pressures. Microscopical examinations were made of the resulting products.

In two experiments the dehydrated kaolin was replaced by a coprecipitated alumina-silica gel having a molar ratio of $1 \mathrm{Al}_{2} \mathrm{O}_{3}: 2 \mathrm{SiO}_{2}$.

\section{RESULTS OF HYDROTHERMAL TREATMENT}

Hypothetical reactions of dehydrated kaolin with the various cement compounds in the presence of water may be represented by the following equations:

$$
\begin{gathered}
3 \mathrm{CaO}+\mathrm{Al}_{2} \mathrm{O}_{3}: 2 \mathrm{SiO}_{2}+2 \mathrm{H}_{2} \mathrm{O}=3 \mathrm{CaO} \cdot \mathrm{Al}_{2} \mathrm{O}_{3} \cdot 2 \mathrm{SiO}_{2} \cdot 2 \mathrm{H}_{2} \mathrm{O} \\
3 \mathrm{CaO}+3 \mathrm{CaO} \cdot \mathrm{Al}_{2} \mathrm{O}_{3}+\mathrm{Al}_{2} \mathrm{O}_{3}: 2 \mathrm{SiO}_{2}+8 \mathrm{H}_{2} \mathrm{O}= \\
2\left(3 \mathrm{CaO} \cdot \mathrm{Al}_{2} \mathrm{O}_{3} \cdot \mathrm{SiO}_{2} \cdot 4 \mathrm{H}_{2} \mathrm{O}\right) \\
\mathrm{CaO}+\beta-2 \mathrm{CaO} \cdot \mathrm{SiO}_{2}+\mathrm{Al}_{2} \mathrm{O}_{3}: 2 \mathrm{SiO}_{2}=3 \mathrm{CaO} \cdot \mathrm{Al}_{2} \mathrm{O}_{3} \cdot 3 \mathrm{SiO}_{2} \\
3 \mathrm{CaO} \cdot \mathrm{SiO}_{2}+\mathrm{Al}_{2} \mathrm{O}_{3}: 2 \mathrm{SiO}_{2}=3 \mathrm{CaO} \cdot \mathrm{Al}_{2} \mathrm{O}_{3} \cdot 3 \mathrm{SiO}_{2}
\end{gathered}
$$

Table 2 permits a comparison of the observed values for the index of refraction of the isometric phase with the theoretical index which would result from complete combination of the cement compound with the aluminum silicate. The values obtained in experiments 20 , 22,23 , and 25 indicate that reactions $1,2,3$, and 4, respectively, proceed almost to completion at the temperatures and with the reaction periods chosen.

Dehydrated kaolin was replaced by coprecipitated alumina-silica gel in experiment 21 . Less of the isometric product was formed and 
it was poorly crystallized compared with that of experiment 20 . In a repetition of experiment 21 , the coprecipitated gel was dehydrated at $700^{\circ}$ prior to mixing with lime. The product of hydrothermal treatment in this case was somewhat better crystallized than that obtained from the undehydrated gel but the difference was not particularly marked.

TABLE 2.-Formation of silica-containing hydrogarnets from mixtures of cement compounds and dehydrated kaolin

\begin{tabular}{|c|c|c|c|c|c|c|c|}
\hline \multirow{2}{*}{$\begin{array}{c}\text { Ex- } \\
\text { peri- } \\
\text { ment } \\
\text { num- } \\
\text { ber }\end{array}$} & \multirow[b]{2}{*}{ Molar ratio of mixture } & \multirow{2}{*}{$\begin{array}{l}\text { Tem- } \\
\text { pera- } \\
\text { ture }\end{array}$} & \multirow[b]{2}{*}{$\begin{array}{l}\text { Pres- } \\
\text { sure }\end{array}$} & \multirow[b]{2}{*}{ Time } & \multicolumn{2}{|c|}{$\begin{array}{l}\text { Index of refraction of iso- } \\
\text { metric phase in product }\end{array}$} & \multirow{2}{*}{$\begin{array}{l}\text { Approxi- } \\
\text { mate } \\
\text { amount } \\
\text { of iso- } \\
\text { metric } \\
\text { phase in } \\
\text { product }\end{array}$} \\
\hline & & & & & Observed & $\begin{array}{l}\text { Theoretical } \\
\text { (assuming } \\
\text { complete } \\
\text { reaction) }\end{array}$ & \\
\hline $\begin{array}{l}19 \\
20 \\
21 \\
22 \\
23 \\
24 \\
25\end{array}$ & $\begin{array}{l}3 \mathrm{CaO}: \mathrm{Al}_{2} \mathrm{O}_{3}: 2 \mathrm{SiO}_{2} \\
3 \mathrm{CaO} 3 \mathrm{CaO} \cdot \mathrm{Al}_{2} \mathrm{O}_{3}: \mathrm{Al}_{2} \mathrm{O}_{3}: 2 \mathrm{SiO}_{2} \\
\mathrm{CaO} ; \mathrm{B}-2 \mathrm{CaO} . \mathrm{SiO}_{2}: \mathrm{Al}_{2} \mathrm{O}_{3}: 2 \mathrm{SiO}_{2} \\
3 \mathrm{CaO} . \mathrm{SiO}_{2}: \mathrm{Al}_{2} \mathrm{O}_{3}: 2 \mathrm{SiO}_{2}\end{array}$ & $\begin{array}{l}{ }^{\circ} C \\
150 \\
350 \\
350 \\
225 \\
500 \\
250 \\
500\end{array}$ & $\begin{array}{r}a t m \\
5 \\
163 \\
163 \\
25 \\
420 \\
39 \\
420\end{array}$ & $\begin{array}{r}\text { Days } \\
14 \\
11 \\
11 \\
14 \\
27 \\
30 \\
7\end{array}$ & $\begin{array}{r}1.64 \text { to } 1.65 \\
1.65 \text { to } 1.66 \\
1.64 \\
1.625 \text { to } 1.63 \\
1.72 \\
1.65 \\
1.70\end{array}$ & $\begin{array}{l}1.675 \\
1.675 \\
1.675 \\
1.63 \\
1.735 \\
1.735 \\
1.735\end{array}$ & $\begin{array}{r}\text { Percent } \\
70 \text { to } 80 \\
80 \text { to } 90 \\
50 \\
90 \\
90 \\
50 \\
80\end{array}$ \\
\hline
\end{tabular}

Well-crystallized preparations were obtained by steaming mixtures of beta-dicalcium silicate, lime, and dehydrated kaolin and of tricalcium silicate and dehydrated kaolin at $500^{\circ} \mathrm{C}$ and 420 atmospheres. The product of experiment 23 , particularly, gave an X-ray pattern which showed practically no shift in lines from the pattern of grossularite garnet. The much slower rate of combination of dehydrated kaolin with tricalcium silicate at $250^{\circ} \mathrm{C}$ than at $500^{\circ} \mathrm{C}$ is illustrated by experiments 24 and 25 .

\section{APPLICATION TO PORTLAND-PUZZOLANA CEMENTS}

The foregoing results cannot be applied directly to an explanation of the high sulfate resistance of portland-puzzolana cements because mortars and concretes made from such cements are usually not subjected to steam curing. Also the initial products of reaction of dehydrated kaolin with lime in the presence of water at ordinary temperatures are different from the isometric crystals obtained at elevated temperatures. As reported by Strätling ${ }^{2}[8]$ and confirmed in unpublished work in this laboratory, the products at room temperature occur as hexagonal plates which are similar in appearance to the hexagonal forms of the hydrated calcium aluminates. These platelike crystals belong to a series of hydrated calcium silicoaluminates which appear to bear a close relationship to the calcium aluminate complex salts.

A sample of one of the hexagonal silicoaluminate preparations, exposed to the sulfate test solution, was about 50 percent converted to the sulfoaluminate in 10 days. After three weeks practically no hexagonal crystals remained. The hexagonal silicoaluminates, therefore appear to be much less resistant than the isometric calcium alumi-

${ }^{2}$ At the time of publication of a previous paper by the authors [6] they had read only a brief report of Strätling's work [9]. This report did not specify the crystalline nature of the product formed by the reaction of dehydrated kaolin with lime solution. It was assumed by the authors that the product might have been an isometric hydrated calcium aluminosilicate or "hydrogarnet." Strätling's publications show that this was not the case. 
nosilicates (hydrogarnets) to transformation by the sulfate solution. This same experiment, however, indicates that the hexagonal compounds probably possess a higher solubility than the hydrogarnets and, if initially protected from sulfate action, should be gradually transformed to the hydrogarnets at ordinary temperatures. Such alteration would lead to increased sulfate resistance of the portlandpuzzolana mortar.

\section{EFFECT OF INCREASE IN GLASS CONTENT ON THE SULFATE RESISTANCE OF CEMENTS}

In a previous paper [6], it was shown that glasses, representative of the compositions of various liquid phases formed in portland cement clinker at $1,400^{\circ} \mathrm{C}$, will react with water at elevated temperatures to give hydrogarnets containing iron and silica. In order to ascertain whether or not similar reactions will occur at ordinary temperatures, powdered samples of three of the glasses used in the former study were made into pastes with 50 percent of their weight of water and stored in sealed vials. The three glasses had the following compositions:

\begin{tabular}{|c|c|c|c|c|}
\hline Flacs & $\begin{array}{c}\mathrm{CaO} \\
\%\end{array}$ & $\begin{array}{c}\mathrm{Al}_{2} \mathrm{O}_{3} \\
\% \\
\%\end{array}$ & $\begin{array}{c}\mathrm{Fe}_{2} \mathrm{O}_{3} \\
\% \\
0\end{array}$ & $\mathrm{SiO}_{2}$ \\
\hline Glass & 56.7 & $\begin{array}{l}50.0 \\
30.3\end{array}$ & 5.0 & 8.0 \\
\hline Glas & 54.8 & 22.7 & 16.5 & 6.0 \\
\hline
\end{tabular}

After 2 months' storage, about 50 percent of glasses $A$ and $B$ had been converted to isometric crystals having indices of refraction of 1.62 and 1.62 to 1.63 , respectively, and about 10 percent of glass $C$ had altered to isometric crystals having a refractive index of 1.64 to 1.65. No separation of hematite or formation of hexagonal calcium aluminate hydrate was observed.

Increase of the glass content of portland cement clinker occurs partly at the expense of crystalline tricalcium aluminate, which is very susceptible to sulfate attack. Thus, reducing the content of tricalcium aluminate and increasing that of the glass, which will hydrate to silica- and iron-containing hydrogarnet, would be expected to improve the sulfate resistance of portland cement. Such improvement, with increase in glass content of cements, has been reported by Parker [5].

\section{EFFECT OF INCREASING ALUMINA-FERRIC OXIDE RATIO ON THE SULFATE RESISTANCE OF CEMENTS}

Cements having a low alumina-ferric oxide ratio are considerably more resistant to sulfate action than those having a high ratio. Compositions of the former type are relatively high in potential tetracalcium aluminoferrite and low in potential tricalcium aluminate, whereas the reverse situation obtains in the latter type.

The much greater sulfate resistance of tetracalcium aluminoferrite than of tricalcium aluminate is explained by the fact, established in a previous study [6], that, when mixed with sufficient water to form a paste, the ferrite hydrates to give an iron-containing hydrogarnet while the aluminate hydrates to iron-free calcium aluminate hydrate. The unit cell size of the isometric phase obtained from a paste of tetracalcium aluminoferrite at room temperature was $12.60 \mathrm{~A}$ (angstroms), or 0.04 A higher than that of $3 \mathrm{CaO} \cdot \mathrm{Al}_{2} \mathrm{O}_{3} \cdot 6 \mathrm{H}_{2} \mathrm{O}$. The unit cube size of $3 \mathrm{CaO}$. 
$\mathrm{Fe}_{2} \mathrm{O}_{3} \cdot 6 \mathrm{H}_{2} \mathrm{O}$ is $12.74 \mathrm{~A}$, or $0.18 \mathrm{~A}$ higher than that of the aluminate. Since a linear relationship exists between unit cube size and composition expressed in mole percent in the series $3 \mathrm{CaO} \cdot \mathrm{Al}_{2} \mathrm{O}_{3} \cdot 6 \mathrm{H}_{2} \mathrm{O}-3 \mathrm{CaO}$. $\mathrm{Fe}_{2} \mathrm{O}_{3} \cdot 6 \mathrm{H}_{2} \mathrm{O}$, a unit cube size of $12.60 \mathrm{~A}$ would correspond approximately to a solid solution containing $0.04 / .018 \times 100=22$ mole percent of $3 \mathrm{CaO} . \mathrm{Fe}_{2} \mathrm{O}_{3} \cdot 6 \mathrm{H}_{2} \mathrm{O}$ in 78 mole percent of $3 \mathrm{CaO} \cdot \mathrm{Al}_{2} \mathrm{O}_{3} \cdot 6 \mathrm{H}_{2} \mathrm{O}$. A sample of tetracalcium aluminoferrite steamed at $225^{\circ} \mathrm{C}$ gave an isometric product having a unit cube size of $12.62 \mathrm{~A}$, corresponding to a solid solution of approximately 33 mole percent of $3 \mathrm{CaO} \cdot \mathrm{Fe}_{2} \mathrm{O}_{3} \cdot 6 \mathrm{H}_{2} \mathrm{O}$ in 67 mole percent of $3 \mathrm{CaO} \cdot \mathrm{Al}_{2} \mathrm{O}_{3} \cdot 6 \mathrm{H}_{2} \mathrm{O}$. Both of these solid solutions would be rather resistant to sulfate action.

\section{SUMMARY}

Experiments on the constituents, and on the possible hydration products, of portland cement indicate that the sulfate resistance of portland cement should be increased by any method resulting in the removal from the set cement of tricalcium aluminate hexahydrate, which is unstable in sulfate solutions, and substitution for the aluminate of hydrogarnets containing iron or silica, which are stable in such solutions. Such substitution may be brought about by: (1) reaction of the hydrated aluminate with silica from the various silicates in the set cement, (2) addition of a puzzolanic material to the cement, and (3) increasing the glass and tetracalcium aluminoferrite contents of the cement.

Additional studies will be necessary to determine to what extent the members of the hydrogarnet solid-solution series are actually formed, or can be made to form in the setting and hardening of various cements and cement-puzzolana mixtures at ordinary temperatures.

Preparations having an X-ray structure nearly identical with that of grossularite garnet resulted when mixtures of beta-dicalcium silicate, lime, and dehydrated kaolin, and also of tricalcium silicate and dehydrated kaolin, were steamed at $500^{\circ} \mathrm{C}$ and 420 atmospheres.

The authors are indebted to H. F. McMurdie for making the X-ray patterns of the garnet preparations.

\section{REFERENCES}

[1] Carlson and Bates, Eng. News-Record 10\%, 130-32 (1931). Gonnerman, Proc. Am. Soc. Testing Materials 34, pt. 2, 244-302 (1934).

Bogue, Lerch, and Taylor, Ind. Eng. Chem. 26, 1049-55 (1934).

Miller and Manson, Proc. Am. Soc. Testing Materials 40, 988--1006 (1940).

[2] Miller, Proc. Am. Soc. Testing Materials 24, pt. 2, 847-61 (1924); 30, pt. 2, 636-53 (1930). Public Roads 5, 203-12 (1927). Thorvaldson, Wolochow, and Vigfusson, Can. J. Research 6, 485-517 (1932). Thorvaldson and Wolochow, J. Am. Concrete Inst. 9, 241-65 (1938).

[3] Lea and Desch, The Chemistry of Cement and Concrete, p. 204 (Edwin Arnold and Co., London, 1935).

[4] Lea, Proc. of the Symposium on the Chemistry of Cements, Stockholm, 1938, 471-81 (Ingeniörsvetenskapsakademien, Stockholm, 1938).

[5] Parker, J. Soc. Chem. Ind. 58 T, 203-13 (1939).

[6] Flint, McMurdie, and Wells, J. Research NBS 26, 13-33 (1941) RP1355.

[7] Flint, McMurdie, and Wells, J. Research NBS 21, 617-38 (1938) RP1147.

[8] Strätling, Ber. deut. keram. Ges. 20, 522-27 (1939); Zement 36, 427-32; 441-45; 455-60; 475-77 (1940).

[9] Büssem, Proc. of the Symposium on the Chəmistry of Cements, Stockholm, 1938, p. 163, 497-98 (Ingeniörsvetenskapsakademien, Stockhlom, 1938).

Washington, June 10, 1941. 